AKRUAL 1 (2) (2010): 171-189 $e$-ISSN: 2502-6380

AKRUAL

Jurnal Akuntansi

http://fe.unesa.ac.id/ojs/index.php/akrl

\title{
PREDIKSI HARGA SAHAM MENGGUNAKAN MODEL VALUASI TEORI SURPLUS BERSIH BERDASARKAN PENDEKATAN OHLSON
}

\author{
Sarah Yuliarini \\ Universitas Wijaya Kusuma \\ Email: sarah_yuliarni@yahoo.com \\ Artikel diterima: 27 Januari 2010 \\ Revisi terakhir: 1 Maret 2010
}

\begin{abstract}
The aim of empirical research is continouing study about clean-surplus theory contributed to valuing firm that listed in Indonesian capital marked. Ohlson (1995) had resolved final counts by assuming that abnormal earning have a regressing time could be counted based on accounting data. The result have to be correlated with marked capitalized. Regression tested refer to positive correlation and significant with marked valued. Valuation adopted Ohlson (1995) count about 130\%, when it could be in post of global monetary crisis, above of marked value differ with prior result. In summary, Ohlson model valuation can be adopted in Indonesia confidently.
\end{abstract}

Keywords: valuation model, abnormal earning, marked capitalized

PENDAHULUAN

Latar Belakang

Pasar modal merupakan pasar dari beberapa instrumen keuangan jangka panjang yang dapat diperjualbelikan. Selain itu, pasar modal juga sebagai salah satu perantara untuk menyalurkan dari pihak-pihak yang kelebihan dana (unit surplus) kepada pihak-pihak yang membutuhkan dana (unit defisit). Pada dasarnya pasar modal menjelaskan dua fungsi utama, yaitu fungsi ekonomi dan fungsi keuangan. Sebagai fungsi ekonomi, pasar modal berfungsi dalam menyediakan dana dari lender ke borrower. Sedangkan sebagai fungsi keuangan, pasar modal berfungsi dalam menyediakan dana tanpa harus terlibat langsung dalam kepemilikan aktiva riil yang diperlukan untuk investasi tersebut (Husnan, 2001).

Pasar modal menyediakan berbagai macam informasi yang dapat digunakan oleh investor. Informasi ini merupakan kebutuhan mendasar bagi para investor dalam pengambilan keputusan investasi. Salah satu informasi yang diharapkan mampu memberi bantuan kepada pemakai dalam membuat keputusan ekonomi yang bersifat finansial adalah laporan keuangan. Laporan keuangan merupakan hasil dari proses 
akuntansi yang disajikan dalam bentuk kualitatif dimana informasi-informasi yang disajikan di dalamnya dapat membantu berbagai pihak (intern dan ekstern) dalam pengambilan keputusan yang sangat berpengaruh bagi kelangsungan hidup perusahaan. Sebagaimana yang dikemukakan dengan jelas oleh Standar Akuntansi Keuangan dalam Kerangka Dasar Penyusunan dan Penyajian Laporan Keuangan adalah sebagai berikut "Tujuan laporan keuangan adalah menyediakan informasi yang menyangkut posisi keuangan, kinerja, serta perubahan posisi keuangan suatu perusahaan yang bermanfaat bagi sejumlah besar pemakai dalam keputusan ekonomi" (IAI, 1994).

Masyarakat luas pada umumnya mengukur keberhasilan perusahaan berdasarkan kemampuan perusahaan yang dilihat dari kinerja manajemen. Kinerja merupakan hasil dari serangkaian proses dengan mengorbankan berbagai sumber daya yang dimiliki suatu perusahaan. Salah satu parameter dalam mengukur kinerja perusahaan adalah informasi tentang earnings (laba) suatu perusahaan. Earnings (laba) adalah kenaikan manfaat ekonomi selama satu periode akuntansi dalam bentuk pemasukan atau perubahan aktiva atau penurunan kewajiban yang mengakibatkan kenaikan ekuitas yang tidak berasal dari kontribusi penanaman modal. Pentingnya informasi laba telah disebutkan dalam SFAC No. 1, Objective of Financial Reporting by Business Enterprise (FASB, 1978), yaitu bahwa selain untuk menilai kinerja manajemen (perusahaan), laba juga dapat digunakan untuk membantu memprediksi laba di masa yang akan datang, serta menaksir risiko dalam investasi atau kredit. Oleh karena itu, informasi laba sebagai indikator kinerja suatu perusahaan merupakan fokus utama dari pelaporan keuangan modern saat ini.

Suatu informasi yang tersedia di pasar modal dapat dianggap bermakna atau bernilai jika keberadaan informasi tersebut menyebabkan investor melakukan transaksi yang tercermin dalam perubahan harga saham. Dengan demikian, seberapa jauh kegunaan informasi dapat disimpulkan dengan mempelajari pengaruh harga saham pada saat informasi tersebut diterima oleh investor. Adanya perubahan harga saham ini akan menyebabkan terjadinya return yang nantinya diterima oleh investor.

Banyak penelitian empiris akuntansi berusaha untuk menemukan nilai relevan value-relevant) atribut akuntansi dalam rangka mempertinggi analisis laporan keuangan. Atribut akuntansi diduga menjadi value-relevant karena atribut akuntansi ini secara statistik berhubungan dengan harga saham.

Peranan pasar modal dan informasi di dalam pasar modal membenarkan penggunaan prediksi reaksi pasar dalam perumusan teori akuntansi (Belkaoui,1987). Wolk et al.(2001) menyatakan bahwa data akuntansi bermanfaat untuk membantu memprediksi variabel keuangan seperti laba, arus kas dan harga sekuritas dalam konteks suatu pasar modal yang efisien (informasi baru bisa direspon dengan cepat oleh pasar dan terefleksi dalam harga saham). Hal ini berarti informasi akuntansi dan pemilihan prosedur pengukuran akuntansi memiliki relevansi yang dapat ditelaah dari reaksi pasar atau pengaruhnya terhadap harga dan return saham (Scott, 2003). Atribut akuntasi mempunyai relevansi nilai karena secara statistik berhubungan dengan harga 
saham (Ou dan Penman,1989) dan penggunaan pilihan prosedur akuntansi berpotensi menyediakan manfaat prediksi yang lebih besar (Watts dan Zimmerman,1986).

Pengujian hubungan laba dengan harga atau return saham diawali oleh penelitian (Ball dan Brown dan Beaver,1968). Penelitian tersebut telah menjadi acuan untuk penelitian lebih lanjut tentang hubungan antara laba dengan return saham. Namun, penelitian tersebut hanya berfokus pada laba agregat sehingga akhir dasawarsa 1980an perhatian peneliti beralih pada koefien respon laba (earnings response coefficient/ERC). Scott (2003) menyatakan bahwa relevansi informasi akuntansi yang lebih banyak mempunyai variabilitis return dan harga saham disebabkan oleh faktor lain dibandingkan oleh perubahan laba itu sendiri.

Kormendi dan Lipe (1987), Collins dan Kothari (1989) dan Easton dan Zmijewski (1989) seperti yang dikutip Wirama (2008) telah mengidentifikasi empat determinan perubahan harga atau ERC yaitu persistensi laba (earnings persistence), risiko, pertumbuhan dan bunga. Kothari (2001) menggunakan hipotesis bahwa harga yang menuntun laba dan adanya laba transitori agaknya merupakan penjelasan yang paling dominan terhadap lemahnya hubungan return saham dengan laba dan untuk besaran ERC, sedangkan Lev (1989) menyatakan bahwa hubungan laba dengan return saham yang lemah diduga disebabkan oleh kelemahan spesifikasi metodologi dalam mengestimasi kedua hubungan tersebut. Hasilnya secara statistik signifikan, tetapi daya penjelas laba hanya antara $2 \%$ sampai $5 \%$ saja.

SFAC No.1 telah menyatakan bahwa fokus utama pelaporan keuangan terletak pada informasi mengenai kinerja suatu perusahaan yang ditunjukkan oleh tolak ukur atas laba dan komponen-komponennya. FASB menyatakan bahwa investor dan kreditor menginginkan informasi laba terutama sebagai indikator potensi arus kas di masa datang.

Laporan Keuangan pada mulanya terdiri atas Laporan Laba Rugi dan Neraca. Kedua jenis ini telah menjadi fokus perhatian dalam teori clean surplus untuk menjelaskan nilai ekuitas perusahaan (Wolk et al., 2001). Fama dam French dalam Damayanti (2000) manyatakan bahwa perusahaan kecil sangat rentan terhadap perubahan kondisi ekonomi dan cenderung kurang menguntungkan. Elton dan Grubber dalam Damayanti (2000) menyatakan bahwa perusahaan dengan ukuran yang lebih besar akan mudah mengakses ke pasar modal dibandingkan dengan perusahaan dengan ukuran kecil. Di samping itu, saham perusahaan kecil tingkat frekuensi perdagangannya tidak secepat dan semudah saham perusahaan besar. Gupta(1969) dalam penelitiannya menemukan bahwa ukuran perusahaan memiliki struktur tertentu, yaitu:

1) Rasio aktivitas dan rasio leverage menurun dengan peningkatan ukuran perusahaan tetapi meningkat dengan pertumbuhan perusahaan.

2) Rasio likuiditas berkembang dengan peningkatan ukuran perusahaan tetapi menurun dengan adanya tingkat pertumbuhan perusahaan.

3) Perusahaan besar cenderung menghasilkan profit margin yang lebih tinggi daripada perusahaan kecil. 
Tingkat Pertumbuhan Perusahaan Pertumbuhan menurut Beaver, Ketter, dan Scholes (1970) dalam Mardiyah (2001) didefinisikan sebagai perubahan tahunan dari total aktiva. Suatu perusahaan yang sedang dalam tahap pertumbuhan akan membutuhkan dana yang besar. Karena kebutuhan dana semakin besar maka perusahaan cenderung menahan sebagian besar pendapatannya. Semakin besar pendapatan yang ditahan menyebabkan semakin kecil deviden yang dibagikan kepada pemegang saham. Tingkat pertumbuhan yang semakin cepat mengindikasikan bahwa perusahaan sedang mengadakan ekspansi. Kegagalan yang disebabkan oleh ekspansi akan meningkatkan beban perusahaan karena perusahaan harus menutup pengembalian beban ekspansi. Hal ini menyebabkan pembagian deviden kepada pemegang saham menurun. Kondisi tersebut diatas dapat menyebabkan investor tidak berminat lagi, sehingga cenderung akan menjual saham yang dimilikinya. Dalam penelitian Andriana (2004) pertumbuhan didefinisikan sebagai perubahan aset tahunan dari total aktiva. Pertumbuhan total aktiva cenderung berdampak positif terhadap leverage perusahaan. Menurut Kaaro (2002) konsep ini didasarkan pada dua argumentasi, pertama, berbeda dengan pertumbuhan penjualan yang setiap usahanya yang dilakukan secara langsung membawa implikasi pada penerimaan. Pertumbuhan aktiva mencerminkan waktu yang lebih panjang dari pertumbuhan penjualan. Kedua, investasi pada aktiva membutuhkan waktu sebelum dioperasikan, sehingga aktifitas yang dilakukan tidak terkait dengan penerimaan. Suatu perusahaan yang sedang dalam tahap pertumbuhan akan membutuhkan dana yang besar sehingga cenderung menahan sebagian besar pendapatannya. Semakin besar pendapatan yang ditahan dalam perusahaan berarti semakin kecil deviden yang dibagikan kepada pemegang saham (Makmun, 2003).

Model valuasi ekuitas secara tradisional menggunakan expected future dividends yang didiskontokan dalam mencari nilai intrinsik firm value dan kemudian dibandingkan dengan harga pasar pada periode amatan. Berbeda dengan hasil penelitian terbaru dari Ohlson (1995) dan Feltham, Ohlson (1995) menyatakan harga sekuritas seharusnya ditentukan oleh nilai buku dan discounted future abnormal earnings. Keuntungan menggunakan pendekatan ini dalam mengukur nilai perusahaan adalah informasi spesifik atas (1) nilai buku, terlepas dari pengaruh hipotesa ekonomi tentang arus kas periode yang akan datang, dan (2) perlakuan atas investasi.

Secara spesifik penelitian ini memfokuskan pada pengukuran perilaku harga saham menggunakan pendekatan Ohlson (1995). Dengan demikian diharapkan dapat menjelaskan pengaruh nilai buku dan abnormal earnings atas perubahan harga ekuitas pada saat krisis. Adapun alasan pentingnya dampak faktor persistensi laba mendatang adalah persistensi laba merupakan indikasi kemampuan laba jangka panjang perusahaan (Penman, 2007) dan kekuatan penjelas laba akuntansi terhadap harga saham di saat krisis. Laba masa datang menjadi basis investor untuk memprediksi aliran kas masa datang dari investasinya terkait harapan harga saham di masa datang (Suwardjono, 2006). 


\section{Rumusan Masalah}

Dari paparan pada latar belakang masalah di atas dapat dikemukakan perumusan masalah, yaitu: Bagaimana memprediksi harga saham menggunakan valuasi teori clean surplus dengan pendekatan Ohlson (1995).

\section{Tujuan Penelitian}

Manfaat yang diharapkan dari hasil penelitian ini adalah dapat memberikan konstribusi untuk:

1. Hendak memberikan bukti empiris aplikasi valuasi menggunakan model clean surplus dengan pendekatan Ohlson pada perusahaan yang terdaftar di Bursa Efek Indonesia terkait dengan prediksi harga saham saat krisis.

2. Menemukan bukti empiris yang mungkin menambah informasi bagi literatur manajemen keuangan mengenai aplikasi model valuasi Ohlson.

3. Praktisi di pasar modal khususnya investor dan pialang untuk mempertimbangkan dan memanfaatkan model valuasi Ohlson berupa informasi mengenai nilai perusahaan dalam rangka memprediksi harga sekuritas secara wajar terutama saat krisis.

4. Melanjutkan dan memberikan dasar bagi penelitian yang berkenaan dengan masalah model valuasi di Indonesia.

\section{TINJAUAN PUSTAKA}

\section{Teori Valuasi}

Teori atau model valuasi merupakan teori atau model yang digunakan untuk menghitung nilai perusahaan, pada umumnya mengacu pada konsep nilai dalam teori ekonomi neoklasik. Berdasarkan teori ekonomi tersebut, nilai sebuah perusahaan adalah sebesar nilai dividen ekspektaksian berupa aliran kas bersih yang akan diterima dari perusahaan tersebut pada masa-masa mendatang). Teknik perhitungan ini lazim disebut dengan teknik kapitalisasi dividen.

Secara teoritis tidak ada kesalahan dalam formulasi kapitalisasi dividen, namun aplikasi praktisnya sulit diterapkan karena setiap orang memiliki preferensi berbeda. Keyakinan yang berbeda akan menghasilkan prediksi yang berbeda mengenai saat dan jumlah dividen yang akan diterima. Karena adanya nilai yang objektif, maka sering dikatakan bahwa nilai adalah sebuah konsep yang tak terdefinisi (Beaver, 1989).

Teori Clean Surplus (surplus bersih)

Asumsi mendasar penilaian harga saham pada hakikatnya ditentukan oleh kekuatan penawaran dan permintaan terhadap saham tertentu di pasar modal (Hartono, 2003). Laporan keuangan merupakan alat utama perusahaan menyampaikan informasi kepada pihak luar perusahaan (FASB, 1978) sehingga laporan keuangan dikatakan mempunyai kandungan informasi bilamana hasil publikasinya menyebabkan timbulnya reaksi pasar. Watts dan Zimmerman (1986) menyatakan bahwa angka-angka akuntansi pada laporan keuangan potensial 
menyampaikan informasi yang berpengaruh terhadap nilai pasar (market value) perusahaan.

Konsep relevansi nilai berkaitan dengan suatu aspek informasi yang mempunyai kemampuan untuk mempengaruhi keputusan investor, kreditor, dan pemakai laporan keuangan lainnya (Epstein dan Mirza, 2003). Ohlson(1995) dan Feltham dan Ohlson (1995) menunjukkan perspektif relevansi nilai dengan menganalisis kegunaan angkaangka akuntansi untuk menilai perusahaan. Teori clean surplus menyediakan suatu rerangka yang konsisten dengan pengukuran yang menunjukkan bahwa nilai pasar tercermin dalam komponen laporan keuangan yaitu pada Neraca dan Laporan Laba Rugi.

Model penilaian Francis dan Schipper (1999) menghubungkan secara langsung kemampuan prediksi yang mendasari relevansi nilai dan market value diproksikan sebagai harga dan return saham. Scott (2003) menyatakan bahwa penelitian tentang prediksi harga saham dan laba merupakan pengujian kemampuan penekatan clean surplus. Penman (2001) menyatakan bahwa praktik penilaian ekuitas atau sekuritas tidak terlepas dengan melibatkan peramalan yang lebih terbatas, memperpendek horizon waktu dan menetapkan suatu model akuntansi kas versus akrual secara khusus.

Model valuasi teori clean surplus mengasumsikan investor memiliki keyakinan dan preferensi yang homogen. Asumsi atau persyaratan adanyan hubungan surplus bersih antara ekuitas dan laba. Hubungan surplus bersih berarti bahwa seluruh perubahan ekuitas selain yang berasal dari transaksi modal, berupa pembagian dividen atau penambahan modal, berasal dari laba perusahaan.

Berikut adalah perumusan teori valuasi yang dikutip dari Wirama (2008) menurut Peasnell,1981;1982.

$$
\mathrm{NB}_{\mathrm{t}}=\mathrm{NB}_{\mathrm{t}-1}+\mathrm{L}_{\mathrm{t}}-\mathrm{D}_{\mathrm{t}}
$$

$\mathrm{NB}_{\mathrm{t}}=$ nilai buku ekuitas tahun t pada perusahaan amatan,

$\mathrm{NB}_{\mathrm{t}-1}=$ nilai buku ekuitas tahun $\mathrm{t}-1$

$\mathrm{L}_{\mathrm{t}}=$ laba yang memenuhi syarat surplus-bersih tahun $\mathrm{t}$ pada perusahaan amatan

$\mathrm{D}_{\mathrm{t}}=$ dividen tahun $\mathrm{t}$ pada perusahaan amatan

Dalam bentuk notasi,perhitungan laba abnormal dapat dinyatakan sebagai berikut:

$$
\mathrm{LAt}=\mathrm{Lt}-((\mathrm{Rf}-1) * \mathrm{NBt}-1)
$$

LA=laba abnormal

$\mathrm{R}=$ tingkat bunga bebas risiko ditambah 1

Berikutnya penggabungan persamaan (1) dan (2) maka akan diperoleh:

$$
\mathrm{D}=\mathrm{LA}-\mathrm{NB}+(\mathrm{Rf} * \mathrm{NBt}-1)
$$


Persamaan ke 3 menunjukkan bahwa dividen dapat dinyatakan berdasarkan data akuntansi, yaitu laba abnormal dan nilai buku ekuitas. Menurut teori ekonomi dinyatakan bahwa dalam jangka panjang perusahaan hanya akan memperoleh laba normal, yaitu laba pada tingkat bunga bebas risiko. Jika dalam kondisi tertentu seperti halnya resesi ekonomi yaitu tingkat laba suatu industri menurun sampai di bawah laba normal, maka sebagian perusahaan akan keluar dari industri sehingga meningkatkan laba perusahaan yang masih bertahan. Hal tersebut dapat dinyatakan dalam notasi pengukuran nilai perusahaan;

$$
\mathrm{NPt}=\sum_{\mathrm{r}=1}^{\infty}(\mathrm{Rf})^{-\mathrm{r}} \operatorname{Et}\left(\mathrm{D}_{\mathrm{t}+\mathrm{r}}\right)
$$

Dengan menggunakan sisi kanan persamaan (3) menggantikan notasi D pada persamaan 4, maka didapat;

$$
\mathrm{NPt}=\mathrm{NB}+\sum_{\mathrm{r}=1}^{\infty}(\mathrm{Rf})^{-\mathrm{r}} \mathrm{Et}\left(\mathrm{LA}_{\mathrm{t}+\mathrm{r}}\right) \ldots \ldots \ldots \ldots \ldots(5)
$$

Persamaan ke 5 dikenal sebagai teori valuasi menunjukkan nilai perusahaan adalah sebesar nilai buku ekuitas ditambah nilai sekarang seluruh laba abnormal yang disebut goodwill. Goodwill dalam teori valuasi memiliki arti yang berbeda dari istilah teknis dalam akuntansi.

Nilai akhir tersebut umumnya menggunakan asumsi tingkat pertumbuhan yang stabil sampai pada waktu yang tak terhingga. Teknik ini memiliki kelemahan dengan tidak adanya dasar teori untuk menentukan nilai akhir sehingga selalu ditetapkan secara ad hoc.

Ohlson(1995) mengatasi masalah penentuan nilai akhir di atas dengan mengasumsikan bahwa laba abnormal memiliki perilaku runtut waktu tertentu sehingga nilai perusahaan dapat dihitung berdasarkan data akuntansi.

\section{Model Ohlson}

Memahami kontribusi Ohlson (1995) dalam teori valuasi diperlukan pemahaman atas dua hal: valuasi laba residual (VLR) dan information Dynamics Ohlson(1995). Valuasi Laba Residual (VLR)

VLR secara logika merupakan ekuivalen atas hipotesis investor pada harga saham berdasar harapan nilai sekarang atas dividen yang akan datang. Meskipun VLR adalah bagian integral dengan model Ohlson, itu sudah ada 50 tahun lalu sebelum Ohlson. VLR dapat ditemukan dalam literatur Preinreich (1938) yang meneliti indikasi VLR atas hipotesis nilai aset terungkap dari nilai dividen yang akan datang. Hal ini dikenal sebagai teknik kapitalisasi dividen. 


$$
\mathrm{NP}=\sum_{\mathrm{r}=1}^{\infty}(\mathrm{Rf})^{-\mathrm{r}} \mathrm{Et}\left(\mathrm{D}_{\mathrm{t}+\mathrm{r}}\right)
$$

$\mathrm{NP}$ adalah nilai perusahaan, Rf adalah satu ditambah suku bunga bebas risiko,D adalah dividen dan notasi Et menunjukkan nilai ekspektasian yang besarnya tergantung pada informasi pada waktu t. Hubungan teknik ini dengan teori clean surplus dijelaskan pada formulasi (1) dan beruntut sampai formulasi (5).

\section{Ohlson's Information Dynamics}

Kontribusi Ohlson (1995) berasal dari modeling atas information dynamics. Model didasarkan atas asumsi perilaku runtut waktu laba abnormal sebagai berikut:

$$
\mathrm{LA}_{\mathrm{t}+1}=\omega \mathrm{Lat}+\mathrm{VLt}+\varepsilon \mathrm{t}+1
$$

$$
\mathrm{VLt}+1=\gamma \mathrm{VL}+\varepsilon \mathrm{t}+1
$$

Dalam persamaan (6a) dan (6b), VL merupakan dampak variabel lain (nonakuntansi) pada nilai perusahaan. VL mencerminkan nilai yang berasal dari transaksi atau kejadian yang mempengaruhi nilai perusahaan tetapi belum terdeteksi oleh akuntansi. Parameter $\omega$ pada persamaan (6a) menunjukkan tingkat persistensi laba abnormal, yaitu berapa persen laba abnormal dalam suatu periode akan diperoleh kembali pada periode berikutnya. Parameter $\gamma$ pada persamaan (6b) menunjukkan persistensi informasi lain (VL). Dengan asumsi bahwa rata-rata laba abnormal dalam jangka panjang adalah nol maka nilai kedua parameter tersebut diasumsikan berada dalam batasan $0 \leq \omega \gamma<1$.

Jika nilai perusahaan adalah sebesar nilai sekarang dividen ekspektasian, dan asumsi hubungan surplus bersih terpenuhi, Ohlson(1995) merumuskan formula perhitungan nilai perusahaan sebagai berikut:

$$
\begin{aligned}
& \mathrm{NPt}=\mathrm{NBt}+\alpha_{1} \mathrm{LAt}+\alpha_{2} \mathrm{VLt} \ldots \ldots \ldots \ldots \ldots \ldots \ldots \ldots \ldots \\
& \text { Dengan } \alpha 1=\frac{\omega}{(\mathrm{Rf}-\omega)} \geq 0 \text { dan } \alpha 2=\frac{\mathrm{Rf}}{(\mathrm{Rf}-\omega)(\operatorname{Rf}-\gamma)}
\end{aligned}
$$

Persamaan (7) dikenal sebagai model Ohlson menunjukkan bahwa nilai perusahaan adalah sebesar nilai buku ekuitas ditambah laba abnormal dan pengaruh variabel lain yang masing-masing dikalikan dengan sebuah konstansta ( $\alpha 1$ dan $\alpha 2$ ). Formulasi nilai perusahaan diturunkan secara sederhana dan berhasil menghilangkan keharusan memprediksi dividen dalam menghitung nilai perusahaan dengan hasil valuasi yang justru identik dengan nilai sekarang seluruh dividen ekspektasian. 
Validitas empiris model tersebut telah pula diuji di beberapa negara dengan hasil yang relatif memuaskan.

Sebagai tambahan atas struktur information dynamic Ohlson(1995) memakai persamaan (7) diderivasi menjadi persamaan return atas pengaruh laba abnormal dan informasi lain.

$$
\text { Ret }=\mathrm{Rf}+\left(1+\alpha_{1}\right) \varepsilon t / \mathrm{NPt}-1+\alpha 2 \varepsilon \mathrm{t} / \mathrm{NPt}-1 \Rightarrow \mathrm{Ret}=(\mathrm{NPt}+\mathrm{Dt}) / \mathrm{NPt}-1
$$

Daya tarik dari model Ohlson(1995) adalah dapat diambil kesimpulan secara empiris dan dapat memperhitungkan nilai perusahaan yang mencerminkan harga saham yang akan datang dengan menggunakan data akuntansi dan non-akuntansi dan hanya menggunakan 3 konstruk dari komponen akuntansi. Lebih lanjut setiap persamaan dapat menggunakan data secara terpisah, dari persamaan (7) menggunakan data nilai buku dan laba yang secara umum sudah digunakan dan diteliti secara empiris. Demikian dengan persamaan (8) secara konsisten dapat menjelaskan hubungan return (abnormal) dan laba yang secara transitory menggunakan dua parameter $\omega$ dan $\gamma$ sehingga laba memiliki persistensi yang tinggi.

Model Ohlson juga dapat dikembangkan dengan prediksi dan kriteria yang ada sesuai dengan kondisi pasar.

\section{Kerangka Teoritis}

Mengacu pada kerangka teoritis di atas, hubungan antar variabel dalam penelitian ini bersifat tertutup (closed-form) yaitu menggunakan perumusan model Ohlson. Pertama untuk mengukur nilai perusahaan yang nanti akan tercermin pada harga saham yang akan datang, perlu dicari persistensi laba abnormal dan persistensi informasi lain. Formulasi (6a), variabel independen dinyatakan dalam LA yang merupakan laba abnormal sekarang dan VL merupakan variable lain sedangkan variable dependen $\mathrm{LA}_{t+1}$ yang merupakan laba abnormal yang akan datang. Pada formulasi (6b) VLt+1 sebagai variable dependen atas variable lain pada periode akan datang, sedangkan variable independent adalah VLt yaitu variable lain periode sekarang. Kedua menentukan return (laba abnormal) menggunakan formulasi (8).

\section{METODOLOGI PENELITIAN}

Penelitian ini menggunakan metode studi mendalam tanpa hipotesis. Data diperlukan untuk pengukuran rumusan.

\section{Populasi dan Sampel}

Populasi diambil dari perusahaan-perusahaan go public yang terdaftar di Bursa Efek Indonesia (BEI) dengan periode waktu sepanjang tahun 2007, 2008 dan 2009. Periode tersebut disesuaikan dengan horizon waktu sebagai event study yaitu saat Indonesia memasuki krisis global tahun 2008. Sampel dilakukan secara purposive sampling yaitu dengan mempertimbangkan kriteria tertentu yaitu: 1) perusahaan 
terdaftar secara aktif pada BEI selama periode amatan 2) perusahaan tidak memiliki ekuitas negatif selama periode amatan.

\section{Metode Pengumpulan Data}

Data diambil dengan sumber sekuder dari Institut Capital Market Directory yang diterbitkan dan sumber langsung dari Bursa Efek Indonesia berupa laporan keuangan Laba Rugi, Neraca dan Arus Kas

\section{Identifikasi Variabel}

Variabel Independen berdasar formulasi (6a),(6b) dan (7):

(1) Variabel laba abnormal (abnormal earnings) LAt adalah laba abnormal yang periode $\mathrm{t}$ berasal dari notasi

(2) Variabel VLt adalah dampak variabel lain (nonakuntansi) pada nilai perusahaan periode sekarang.. Variabel ini mencerminkan nilai yang berasal dari transaksi atau kejadian yang mempengaruhi nilai perusahaan tetapi belum

(3) Variabel NBt adalah nilai buku ekuitas tahun t pada perusahaan amatan pada formulasi (7)

Variabel Dependen:

(1) Pada notasi (6a) adalah LAt+1 adalah laba abnormal yang akan datang. Variabel lain yang terdapat pada notasi ke 2 .

(2) Notasi (6b) adalah VLt+1 adalah dampak variabel lain (nonakuntansi) pada nilai perusahaan periode yang akan datang.

(3) Pada notasi (7) NPt adalah nilai perusahaan adalah sebesar nilai buku ekuitas ditambah nilai sekarang seluruh laba abnormal.

\section{Teknik Pengumpulan Data}

Adapun langkah-langkah yang dilakukan dalam penelitian ini adalah:

1. Data dikumpulkan dari buku yang diterbitkan oleh Institute for Economic and Financial Research 2007, 2008 dan 2009 data Laporan Keuangan yang berupa Catatan Manajemen

2. Memasukkan data ke dalam sel analisis.Memasukkan data ke rumus.

3. Analisis hipotesis menggunakan alat statistika berdasarkan notasi (6a),(6b), dan notasi (7)

4. Menghitung return (abnormal) menggunakan formulasi (8)

5. Membandingkan dengan aktual stock price pada tahun amatan

6. Menyimpulkan hasil analisis dan membuat kesimpulan umum penelitian. 


\section{Metode Analisis Data}

a. Uji normalitas, yaitu dengan one sample Kolmogorov Smirnov atas variabelvariabel independen, guna melihat normalitas distribusi populasi sehingga dapat ditentukan alat analisisnya pada tingkat signifikansi $\mathrm{p}<5 \%$

b. Uji deskriptif, menentukan koefisien parameter persistensi laba abnormal adalah nol $(\omega=0)$, parameter persistensi dampak informasi lain pada nilai perusahaan. $(\gamma$ $<1)$.

c. Uji korelasi guna mendapat tingkat hubungan antara hasil valuasi Ohlson (1995) dan harga pasar.

d. Menghitung return (abnormal) menggunakan formulasi (8)

e. Menyimpulkan hasil analisis dan membuat kesimpulan umum penelitian. Menurut relativitas teori prediksi menggunakan valuasi model Ohlson, penelitian ini diharapkan dari nilai buku dan abnormal earnings memiliki korelasi positif dengan harga saham.

Analisis pengujian terhadap hipotesis akan dilakukan dengan menggunakan analisis statistika yang menggunakan alat bantu statistik uji Regresi Sederhana.

\section{PEMBAHASAN}

Nilai intrinsik perusahaan, yaitu nilai yang sebenarnya berdasarkan faktor-faktor fundamentalnya tidak pernah dapat diketahui, bahkan mungkin tidak diketahui, bahkan mungkin tidak ada karena konsep nilai selalu bersifat subyektif (Beaver,1989). Harga pasar dapat dipandang sebagai simpulan bersama para investor dalam menentukan nilai intrinsik perusahaan. Oleh karena itu, pengujian validitas empiris model valuasi pada umumnya dilakukan dengan membandingkan hasil valuasi tersebut dengan harga pasar. Sebagai contoh, hal tersebut telah dilakukan oleh McRae dan Nilsson (2001) dengan menggunakan data pasar modal Swedia dan menemukan adanya korelasi positif yang secara statistis signifikan antara hasil valuasi model Ohlson dan harga pasar. Simpulan yang serupa dihasilkan pula oleh Dechow, Hutton, dan Sloan (1999) yang menguji model Ohlson dengan menggunakan data pasar modal Amerika. Namun, berdasarkan kedua penelitian tersebut, rata-rata hasil valuasi model Ohlson masih 26 samapi 29 persen lebih rendah daripada harga pasar. Di Indonesia, hasil pengujian yang konsisten dengan kedua penelitian di atas ditunjukkan oleh Wirama (2008). Dengan jumlah amatan 510 perusahaan tahun(1999 sampai dengan 2005),Wirama (2008) menemukan korelasi positif yang secara statistis antara harga pasar dan hasil valuasi model Ohlson $(\mathrm{r}=0.755 ; \mathrm{p}<0.01)$ dan antara perubahan harga pasar dan perubahan hasil valuasi dari tahun ke tahun ( $\mathrm{r}$ berkisar dari 0.225 sampai 0.434; $\mathrm{p}<0.01$ ). Namun, serupa dengan temuan McRae dan Nilsson (2001) serta Dechow, Hutton, dan Sloan (1999), hasil valuasi model Ohlson di Indonesia secara rata-rata masih 18,5 persen lebih rendah daripada harga pasar.

Dalam penelitian ini periode diambil disekitar krisis global yang dimulai pada tahun 2008 hingga 2009. Sampel sebanyak 41 perusahaan diambil secara acak dari perusahaan yang terdaftar di Bursa Efek Indonesia dengan syarat tidak memiliki 
ekuitas negatif selama periode tersebut. Agar diperoleh periode estimasi yang lebih panjang maka parameter model Ohlson (1995) diestimasi dengan menggunakan data semesteran selama 3 semester yang dimulai semester 1 tahun 2008 (1 Januari- 30 Juni), semester 2 tahun 2008 (1 Juli-31 Desember) hingga semester 3 tahun 2009 (1 Januari-30 Juni). Tingkat bunga bebas resiko digunakan adalah rata-rata SBI bulanan yang dikeluarkan Bank Indonesia dari tahun 2008 sampai dengan 2009.

Tabel 1 berdasarkan tabel statistis 4a menunjukkan adanya hasil koefisien persistensi laba abnormal $(\omega)$ sebesar 0,373 dan persistensi dampak variabel lain $(\gamma)$ sebesar 0,537 sesuai dengan kriteria yaitu $0 \leq \omega \gamma<1$. Kriteria ini ditetapkan Ohlson(1995) mengasumsikan bahwa nilai parameter tersebut adalah tetap dan diketahui. Hasil valuasi yang tidak sesuai dengan harapan kemungkinan disebabkan dilanggarnya persyaratan model ini.

Tabel 2 menunjukkan perhitungan rata-rata valuasi Ohlson adalah 130\% lebih tinggi daripada harga pasar dengan kondisi 18 perusahaan berada dalam kelompok saham yang cenderung terharga-lebih dan 23 perusahaan berada dalam kelompok saham yang cenderung terharga-kurang. Berdasarkan uji korelasi antara perhitungan model Ohlson (OM) dan nilai pasar atau actual price (NP) menunjukkan korelasi positif yang secara statistis signifikan (tabel 4b). Hal ini menunjukkan model Ohlson dapat diterapkan dalam kondisi selama krisis ekonomi. Adanya harapan bahwa pasca krisis kondisi pasar lebih dinamis setelah mengalami goncangan krisis global awal 2008, menyebabkan perhitungan akhir valuasi diatas harga pasar, berbeda dengan hasil penelitian sebelumnya.

Tabel 3 merupakan perhitungan return yang menunjukkan keberadaan laba abnormal dan dampak variabel lain. Berdasarkan perhitungan tersebut rata-rata tingkat return pada kondisi krisis sama dengan satu ditambah tingkat bunga bebas risiko (Rf). Dimana dalam perhitungan $\mathrm{Rf}$ sebesar 1,0824 dan rata-rata return sebesar 1,082413 . 
Tabel 1. Hasil Perhitungan Valuasi Ohlson

$$
\begin{aligned}
& \mathrm{LA}_{t+1}=\omega \mathrm{Lat}+\mathrm{VL} t+\varepsilon_{t+1} \\
& \mathrm{VL}_{t+1}=\gamma \mathrm{VL}+\varepsilon_{t+1}
\end{aligned}
$$

\begin{tabular}{|c|c|c|c|}
\hline No & Nama & LA $t+1$ & VL $t+1$ \\
\hline 1 & AALI & 202650.2906 & 262.5243535 \\
\hline 2 & ALMI & -33985.012 & -93.2482142 \\
\hline 3 & ASRI & -12499.0475 & 2.085335804 \\
\hline 4 & ANTM & -98070.4139 & 5.061637273 \\
\hline 5 & AQUA & 728.0318636 & 1583.087103 \\
\hline 6 & ASII & 894915.3579 & 562.8189285 \\
\hline 7 & AUTO & 59693.58268 & 218.4245943 \\
\hline 8 & BATA & -4856.03413 & 109.2303438 \\
\hline 9 & BRAM & -12777.2454 & 0.082185703 \\
\hline 10 & BRNA & -2184.46229 & 24.42224875 \\
\hline 11 & BUDI & 25791.90503 & 12.57876025 \\
\hline 12 & PGAS & 1470320.498 & 97.49893616 \\
\hline 13 & CEKA & 7798.230307 & 66.64599551 \\
\hline 14 & CMNP & -33270.1071 & 7.9210597 \\
\hline 15 & CPIN & 25457.82804 & 23.50641057 \\
\hline 16 & CTRS & -18338.3023 & 10.93127959 \\
\hline 17 & DPNS & -48965.1434 & 7.769744276 \\
\hline 18 & DVLA & 2903.719359 & 40.04416576 \\
\hline 19 & DYNA & -355.916121 & 0.251388242 \\
\hline 20 & EKAD & 1337.29813 & 8.025076663 \\
\hline 21 & ELTY & -19309.8094 & 1.534274826 \\
\hline 22 & EPMT & 25813.32634 & 34.78477721 \\
\hline 23 & ESTI & -1761.41449 & 5.030394998 \\
\hline 24 & FAST & 15910.60429 & 79.90824351 \\
\hline 25 & FASW & -16786.9756 & 11.21329231 \\
\hline 26 & GDYR & 14243.50363 & 803.6654508 \\
\hline 27 & GGRM & 130069.204 & 399.9035278 \\
\hline 28 & HITS & -54605.9392 & -6.39850797 \\
\hline 29 & HMSP & 766105.5749 & 309.1251588 \\
\hline 30 & IGAR & -2087.13738 & 4.822080273 \\
\hline 31 & IKBI & -2791.9999 & 43.73582207 \\
\hline 32 & INAI & 5204.203886 & 81.98997375 \\
\hline 33 & INDF & 143565.9279 & 48.9108012 \\
\hline 34 & INDS & 12781.9625 & 571.9407587 \\
\hline 35 & ISAT & -422648.086 & 11.8112787 \\
\hline 36 & JECC & -379.304866 & 14.99892143 \\
\hline 37 & JIHD & 3274.15721 & 33.58128961 \\
\hline 38 & JPRS & -16591.9481 & -1064.2937 \\
\hline 39 & AKRA & -31892.7666 & 0.018943346 \\
\hline 40 & UNTR & 557383.7464 & 1341.002128 \\
\hline
\end{tabular}




\begin{tabular}{cccc}
\hline No & Nama & LA $\mathbf{t}+\mathbf{1}$ & VL $\mathbf{t + 1}$ \\
\hline 41 & UNVR & 484930.7261 & 105.2357422 \\
Koefisien $\boldsymbol{\omega}=\mathbf{0 . 3 7 3}$ & & \\
Koefisien $\boldsymbol{\gamma}=\mathbf{0 . 5 3 7}$ & & \\
\hline
\end{tabular}

Tabel 2 Perhitungan Model Ohlson (OM)

$$
\mathrm{NPt}=\mathrm{NBt}+\alpha_{1} \mathrm{LAt}+\alpha_{2} \mathrm{VLt}
$$

\begin{tabular}{|c|c|c|c|c|c|c|}
\hline No & Nama & $\mathbf{O M}$ & NP & $\%$ & Prediksi & Aktual \\
\hline 1 & AALI & 7814028.109 & 26534453 & 0.294486 & 4962.091 & 10850 \\
\hline 2 & ALMI & 1156854.201 & 172480 & 6.707179 & 3756.02 & 980 \\
\hline 3 & ASRI & 1808680.422 & 1874073 & 0.965107 & 105.5929 & 109 \\
\hline 4 & ANTM & 10178572.12 & 19315381 & 0.526967 & 1067.425 & 2025 \\
\hline 5 & AQUA & 1105975.781 & 3222173 & 0.343239 & 84024.92 & 244800 \\
\hline 6 & ASII & 84486509.16 & 96350856 & 0.876863 & 20869.34 & 23800 \\
\hline 7 & AUTO & 4276205.507 & 2409867 & 1.774457 & 5545.179 & 3125 \\
\hline 8 & BATA & 268917.2867 & 391950 & 0.686101 & 20685.95 & 30150 \\
\hline 9 & BRAM & 944688.41 & 810000 & 1.166282 & 4.198615 & 1800 \\
\hline 10 & BRNA & 186589.229 & 86940 & 2.146184 & 1352.096 & 630 \\
\hline 11 & BUDI & 1726276.32 & 694665 & 2.485049 & 459.5112 & 185 \\
\hline 12 & PGAS & 12092245.61 & 75473717 & 0.160218 & 498.824 & 3150 \\
\hline 13 & CEKA & 294819.7796 & 306425 & 0.962127 & 990.9909 & 1030 \\
\hline 14 & CMNP & 1385077.704 & 1880000 & 0.736743 & 1234.472 & 940 \\
\hline 15 & CPIN & 1499972.392 & 2134965 & 0.702575 & 456.6736 & 650 \\
\hline 16 & CTRS & 1415780.471 & 1009221 & 1.402845 & 715.4508 & 510 \\
\hline 17 & DPNS & 36355.53254 & 1517000 & 0.023965 & 109.7923 & 820 \\
\hline 18 & DVLA & 528501.7752 & 856800 & 0.616832 & 943.7532 & 1530 \\
\hline 19 & DYNA & 431624.4248 & 292676 & 1.474752 & 1371.519 & 350 \\
\hline 20 & EKAD & 68032.59402 & 58697 & 1.159047 & 121.6997 & 105 \\
\hline 21 & ELTY & 4537365.917 & 5875247 & 0.772285 & 227.8243 & 295 \\
\hline 22 & EPMT & 178590.8103 & 1983600 & 0.090034 & 78.3293 & 870 \\
\hline 23 & ESTI & 265495.3613 & 1428000 & 0.185921 & 131.7458 & 55 \\
\hline 24 & FAST & 571377.6313 & 3592939 & 0.159028 & 1280.398 & 3200 \\
\hline 25 & FASW & 1335937.186 & 307500 & 4.344511 & 539.1433 & 1450 \\
\hline 26 & GDYR & 375706.4652 & 24147304 & 0.015559 & 9163.572 & 7500 \\
\hline 27 & GGRM & 16462052.85 & 2843322 & 5.789725 & 8555.769 & 12550 \\
\hline 28 & HITS & 1600463.619 & 40761900 & 0.039264 & 343.3599 & 610 \\
\hline 29 & HMSP & 8994145.638 & 110250 & 81.57955 & 2052.052 & 9300 \\
\hline 30 & IGAR & 190978.7846 & 443700 & 0.430423 & 190.5392 & 105 \\
\hline 31 & IKBI & 489872.3882 & 30413 & 16.10734 & 1600.89 & 1450 \\
\hline 32 & INAI & 63787.25153 & 16595006 & 0.003844 & 483.2368 & 192 \\
\hline 33 & INDF & 9016762.382 & 50625 & 178.1089 & 1026.916 & 1890 \\
\hline 34 & INDS & 164757.9317 & 27033819 & 0.006095 & 4393.545 & 1350 \\
\hline 35 & ISAT & 16929950.03 & 52920 & 319.9159 & 3115.598 & 4725 \\
\hline 36 & JECC & 90881.64844 & 762365 & 0.11921 & 601.0691 & 240 \\
\hline 37 & JIHD & 1301126.864 & 64400 & 20.20383 & 674.1453 & 395 \\
\hline 38 & JPRS & 216653.7393 & 232500 & 0.931844 & 14443.58 & 310 \\
\hline 39 & AKRA & 1593278.11 & 2562828 & 0.621687 & 508.8643 & 820 \\
\hline
\end{tabular}




\begin{tabular}{|c|c|c|c|c|c|c|}
\hline No & Nama & $\mathbf{O M}$ & NP & $\%$ & Prediksi & Aktual \\
\hline 40 & UNTR & 13088536.85 & 33102429 & 0.395395 & 17451.38 & 9950 \\
\hline 41 & UNVR & 3600539.113 & 70577500 & 0.051015 & 471.8924 & 9250 \\
\hline \multicolumn{4}{|c|}{$\begin{array}{l}\text { Rata-rata valuasi Ohlson Model (OM) } \\
\text { terhadap harga pasar(NP) }\end{array}$} & 15.97761 & 2.300117 & \\
\hline \multicolumn{4}{|c|}{ Mean OM $\quad 5189608.9$} & & 5283.155 & \\
\hline \multicolumn{2}{|c|}{ Median OM } & \multicolumn{2}{|c|}{1301126.8640} & & 990.991 & \\
\hline \multicolumn{2}{|c|}{ Maksimum } & \multicolumn{2}{|c|}{84486509.16} & & 84024.92 & \\
\hline \multicolumn{2}{|c|}{ Minimum } & \multicolumn{2}{|c|}{36355.53} & & 4.2 & \\
\hline \multicolumn{4}{|c|}{ Koefisien $\alpha 1=0.525796$} & & & \\
\hline \multicolumn{4}{|c|}{ Koefisien $\alpha 2=2.797573$} & & & \\
\hline
\end{tabular}

Tabel 3. Perhitungan Return (Abnormal)

$$
\text { Ret }=\mathrm{Rf}+\left(1+\alpha_{1}\right) \varepsilon t / \mathrm{NPt}_{-1}+\alpha 2 \varepsilon t / \mathrm{NPt}_{-1}
$$

\begin{tabular}{rllr}
\hline No & & Nama & Ret \\
\hline 1 & AALI & 1.082401 \\
2 & ALMI & 1.082404 \\
3 & ASRI & 1.082402 \\
4 & ANTM & 1.0824 \\
5 & AQUA & 1.082404 \\
6 & ASII & 1.0824 \\
7 & AUTO & 1.082401 \\
8 & BATA & 1.082416 \\
9 & BRAM & 1.082405 \\
10 & BRNA & 1.082423 \\
11 & BUDI & 1.082403 \\
12 & PGAS & 1.0824 \\
13 & CEKA & 1.082415 \\
14 & CMNP & 1.082403 \\
15 & CPIN & 1.082403 \\
16 & CTRS & 1.082403 \\
17 & DPNS & 1.082519 \\
18 & DVLA & 1.082408 \\
19 & DYNA & 1.08241 \\
20 & EKAD & 1.082464 \\
21 & ELTY & 1.082401 \\
22 & EPMT & 1.082424 \\
23 & ESTI & 1.082416 \\
24 & FAST & 1.082408 \\
25 & FASW & GDYR & 1.082403 \\
26 & GGRM & 1.082412 \\
28 & HITS & 1.0824 \\
29 & HMSP & IGAR & 1.082403 \\
31 & IKBI & 1.0824 \\
& & 1.082423 \\
& 1.082409 \\
\hline
\end{tabular}




\begin{tabular}{rrrr}
\hline No & & Nama & \multicolumn{1}{r}{ Ret } \\
\hline & 32 & INAI & 1.082468 \\
& 33 & INDF & 1.0824 \\
& 34 & INDS & 1.082426 \\
35 & ISAT & 1.0824 \\
36 & JECC & 1.082448 \\
37 & JIHD & 1.082403 \\
38 & JPRS & 1.08242 \\
39 & AKRA & 1.082403 \\
40 & UNTR & 1.0824 \\
41 & UNVR & 1.082401 \\
\hline
\end{tabular}

Tabel 4a. Statistis Parameter Persistensi Laba Abnormal dan Persistensi Variabel Lain

Coefficients $\omega=0.373$ (LAt)

\begin{tabular}{|c|c|c|c|c|c|c|}
\hline & \multicolumn{3}{|c|}{$\begin{array}{l}\text { Unstandardized } \\
\text { Coefficients }\end{array}$} & $\begin{array}{c}\text { Standardized } \\
\text { Coefficients }\end{array}$ & $\mathrm{t}$ & Sig. \\
\hline Model & & B & Std. Error & Beta & & \\
\hline \multicolumn{4}{|c|}{1 (Constant)179507701210.360146475662877.721 } & & 1.226 & .228 \\
\hline & LANOW & .373 & .187 & .306 & 1.991 & .054 \\
\hline & VLT & 133860324.732 & 187189304.520 & .110 & .715 & .479 \\
\hline
\end{tabular}

a Dependent Variable: LATPLUS

Coefficients $\gamma=0.537$ (VLt)

\begin{tabular}{|c|c|c|c|c|c|c|}
\hline & & $\begin{array}{l}\text { idardized } \\
\text { ficients }\end{array}$ & & $\begin{array}{l}\text { Standardized } \\
\text { Coefficients }\end{array}$ & $\mathrm{t}$ & Sig. \\
\hline \multirow{3}{*}{ Model } & & B & Std. Error & Beta & & \\
\hline & (Constant) & 64.178 & 115.591 & & .555 & .582 \\
\hline & VLT & .537 & .149 & .500 & 3.606 & .001 \\
\hline
\end{tabular}

a Dependent Variable: VLPLUS 
Tabel 4b. Korelasi Hasil Ohlson Model (OM) dan Nilai Pasar (NP)

Descriptive Statistics

\begin{tabular}{lrcr}
\hline & Mean & Std. Deviation & N \\
\hline OM & 5189608.9610 & 13521891.4221 & 41 \\
NP & 11413436.7317 & 22442241.2024 & 41 \\
\hline
\end{tabular}

Correlations

\begin{tabular}{crrr}
\hline & & & OM \\
\hline OM & Pearson Correlation & 1.000 & .651 \\
& Sig. (1-tailed) &. & .000 \\
NP & Pearson Correlation & 41 & 41 \\
& Sig. (1-tailed) & .651 & 1.000 \\
& $\mathrm{~N}$ & .000 & \\
& & 41 & 41 \\
\hline ** Correlation
\end{tabular}

** Correlation is significant at the 0.01 level (1-tailed).

\section{SIMPULAN DAN SARAN}

\section{Simpulan}

Hasil pengujian empiris menunjukkan bahwa model Ohlson(1995) menghasilkan nilai yang berasosiasi dengan harga pasar. Meskipun hasil valuasi tersebut masih berbeda dari harga pasar, adanya korelasi positif mengindikasikan model Ohlson masih aplikatif dan dapat dikembangkan lebih akurat. Hasil penelitian ini mendukung hasil yang dilakukan Wirama (2008) untuk metode yang sama dengan periode yang berbeda, meskipun rata-rata perhitungan Ohlson berbeda. Wirama (2008) menemukan dari data tahun 1999 sampai dengan 2005 prediksi OM dibawah harga pasar, sebaliknya hasil penelitian ini menunjukkan rata-rata hasil valuasi OM diatas harga saham. Dengan perbedaan kondisi pasar yang sedang krisis. Hal ini mencerminkan masih terbukanya penelitian lebih lanjut. 


\section{Saran}

Beberapa kemungkinan penelitian yang dapat dieskplorasi adalah:

1. Identifikasi faktor-faktor yang mempengaruhi laba abnormal

2. Identifikasi kondisi perusahaan atau industri yang mempengaruhi kinerja teori clean surplus dalam menjelaskan harga pasar.

3. Spesifikasi pola linear information dynamic yang lebih tepat. 


\section{DAFTAR PUSTAKA}

Baltagi,B.H.,dan Raj,B.(1992)"A Survey of recent theoretical development in the econometrics of panel data", Empirical Economics, 17,85-109

Ball,R. dan J.M.Wahlen.2003.'Residual Income Risk, Intrinsic Vales, and Share Prices". The Accounting Review 78 (1):327-351.

Beaver,W.H.1989. Financial Reporting:An Accounting Revolution.2 ${ }^{\text {nd }}$ Edition.Englewwod Cliffs,NJ.

Febriyanti, Galuh Artika.2004. Perbandingan Keakuratan Model Laba Permanen, Transitori dan Agregat dalam Memprediksi Laba Masa Depan. Makalah. Simposium Nasional Akuntansi VII.Bali

Francis J. Ohlson P. Dan Oswald D.2000.'Comparing the accuracy and explainability of dividend, free cash flow, and abnormal earnings equity value estimates", Journal of Accounting Research, Vol.38,45-70

Hanlon, M.2005. The Persistence and Pricing Earnings, Accrual, and cash Flows when firm have large box-tax difference. The Accounting Review.80(March), 137-166

IASC.2000. International Accounting Standards Explained. John Wiley \& Sons. New York

Karathanassis,G. 1981. 'Empirical Valuation Models: How Useful Have They Been?", Accounting and Business Research.

Karathanassis,G., dan Philippas, N. 1988. "Estimation of bank stock price parameters and the variance components model",Applied Economics,20,497507.

Karathanassis,G., dan Spilioti S. 2003. "An Empirical Investigation of the Traditional and the clean surplus valuation model", Managerial Finance.

Kormendi,R. dan R.Lipe.1987. Earnings Innovations,Earnings Persistence, and Stock Returns. Journal of Bussiness,60(March), 323-345

Miller M.,dan Modilgianni F.1961. Dividend Policy, Growth and the valuation of share", The Journal of Business. Vol.XXXIV,411-433

Ohlson J. 1990. "A synthesis of Security Valuation Theory and the Role of Dividends, Cash Flows, and Earnings", Contemporary Accounting Research Vol.6,648-676

Ohlson J.1991. "The Theory of Value and earnigs and an Introduction to the BallBrown Analysis", Contemporary Accounting Research Vol.11,661-687

Ohlson J. 1995. "Earnings Book Values and Dividends in Security Valuation", Contemporary Accounting Research, Vol.11,661-687.

Watts,R.L.2003."Conservatism in Accounting Part I: Explanation and Implication", Accounting Horizons 17(3):207-221.

Williams J.B. 1938. The Theory of Investment Values. Harvard University Press

Wirama.D.G. 2008. Teori Surplus Bersih:Valuasi Perusahaan Berdasarkan Data Akuntansi. Tesis.Univ.Udayana 